\title{
JENIS-JENIS BELAJAR MATEMATIKA
}

\author{
Oleh: A.Ika Prsasti Abrar \\ Program Studi Pendidikan Matematika Fakultas Tarbiyah STAIN Palopo \\ e-mail: asty_math03@yahoo.co.id
}

\begin{abstract}
Abstrak:
Belajar adalah sebuah proses mental dari seseorang yang melakukannya. Ini berarti mendeteksi orang belajar atau tidak, bukanlah hal yang mudah. Dua orang sedang membaca buku yang sama secara bersamaan tidak dapat divonis bahwa mereka melakukan kegiatan belajar. Boleh jadi keduanya belajar, salah satunya atau mungkin dari keduanya tak ada yang belajar. Sebelum dijelaskan pengertian belajar matematika maka terlebih dahulu dikemukakan tentang karakteristik matematika. Terdapat enam karakteristik matematika yaitu: obyek kajiannya bersifat abstrak, memilikii simbol yang kosong dari arti, konsisten dalam sistemnya, dibatasi oleh semesta pembicaraan, berpola pikir deduktif, dan bertumpu pada kesepakatan. Selain itu salah satu ciri khas dari matematika adalah memiliki sifat hirarkis. Mengenal karakteristik dan sifat dari matematika akan lebih memudahkan untuk mempelajari matematika.
\end{abstract}

Kata Kunci: Belajar Matematika

\section{Pendahuluan}

Belajar dan pembelajaran adalah dua kata yang berkait erat dalam dunia pendidikan. Belajar banyak didefinisikan oleh para ahli dengan kalimat berbeda namun memiliki substansi kajian yang sama. Belajar adalah suatu upaya sadar yang dilakukan seseorang. Artinya belajar itu melibatkan mental bagi setiap pembelajar.

Pembelajaran dari segi bahasa menunjukkan ada pihak lain selain orang yang belajar. Degeng dalam Ratumanan (2004) mengatakan bahwa pembelajaran merupakan upaya untuk membelajarkan siswa. Pembelajaran lebih cenderung berarti bagaimana membuat seseorang belajar. Dalam pembelajaran ada yang memberi stimulus (rangsangan) sehingga memunculkan respon (tanggapan). Hal ini sering terkait antara seorang siswa atau murid dengan seorang guru dalam pembelajaran.

Pada pembahasan selanjutnya yang akan dibicarakan dalam makalah ini adalah telaah tentang belajar secara umum dan belajar matematika secara khusus.

\section{Pembahasan}

\section{Pengertian Belajar}

Belajar adalah sebuah proses mental dari seseorang yang melakukannya. Ini berarti mendeteksi orang belajar atau tidak, 
bukanlah hal yang mudah. Dua orang sedang membaca buku yang sama secara bersamaan tidak dapat divonis bahwa mereka melakukan kegiatan belajar. Boleh jadi keduanya belajar, salah satunya atau mungkin dari keduanya tak ada yang belajar.

Mendeteksi seseorang belajar atau tidak, dapat dilakukan dengan tes hasil belajar. Apabila dalam hasil tes belajar diperoleh informasi bahwa ada perubahan perilaku dari pembelajar berarti seseorang dapat dianggap telah belajar. Hampir semua pakar pendidikan mengakui bahwa pengetahuan dari hasil belajar itu sifatnya harus lebih permanen.

Pengertian belajar oleh para pakar secara tekstual berbedabeda tetapi substansinya sama. Antara satu pakar dengan pakar lainnya saling melengkapi dan saling memperkuat.

Morgan dalam Ratumanan (2004) mengatakan belajar adalah setiap perubahan tingkah laku yang permanen dan terjadi dari hasil pelatihan atau pengalaman. Sedangkan menurut Ormord dalam Ratumanan (2004) menggambarkan dua definisi belajar yang berbeda yaitu "Learning is a relatively permanent change in behavior due to experience" (belajar adalah perubahan perilaku yang relatif permanen karena pengalaman). Kedua "Learning is a relatively permanent change in mental associations due to experience" (belajar merupakan perubahan mental yang relatif permanen karena pengalaman).

Dari beberapa pengertian belajar yang dikemukakan, Ratumanan (2004) memberikan beberapa karakteristik tentang belajar yaitu:

1. belajar melahirkan perubahan pada diri individu

2. bahwa perubahan dari hasil belajar tersebut memberikan kemampuan baru untuk merespon situasi tertentu.

3. perubahan yang terjadi bersifat lebih permanen atau dapat bertahan lebih lama.

4. belajar itu membawa perubahan yang disebabkan oleh usaha sengaja (sadar) atau bukan sesuatu yang otomatis.

\section{Pengertian Belajar Matematika}

Sebelum dijelaskan pengertian belajar matematika maka terlebih dahulu dikemukakan tentang karakteristik matematika. Terdapat enam karakteristik matematika yaitu: obyek kajiannya bersifat abstrak, memilikii simbol yang kosong dari arti, konsisten dalam sistemnya, dibatasi oleh semesta pembicaraan, berpola pikir deduktif, dan bertumpu pada kesepakatan. Selain itu salah satu ciri khas dari matematika adalah memiliki sifat hirarkis. 
53 | al-Khwarizmi, Volume III, Edisi 1, Maret 2015, Hal. 51 - 62.

Mengenal karakteristik dan sifat dari matematika akan lebih memudahkan untuk mempelajari matematika.

Pada dasarnya belajar membutuhkan keterlibatan mental. Dalam belajar matematika terjadi proses berpikir, sebab seseorang dikatakan berpikir bila orang itu melakukan kegiatan mental dan orang yang belajar matematika mesti melakukan kegiatan mental. Mempelajari matematika berbeda dengan mempelajari ilmu-ilmu lain. Belajar matematika berkenaan dengan ide atau konsep abstrak. Keterlibatan simbol-simbol yang tersusun secara hirarkis serta penalarannya deduktif, sehingga belajar matematika itu membutuhkan keterlibatan mental yang tinggi.

Dalam berpikir, orang menyusun hubungan-hubungan antara bagian-bagaian informasi yang telah direkam di dalam pikiran orang itu sebagai pengertian-pengertian. Dari pengertian tersebut terbentuklah pendapat yang pada akhirnya ditariklah kesimpulan. Tentunya kemampuan berpikir seseorang itu dipengaruhi oleh inteligensinya. Dengan demikian terlihat adanya kaitan antara inteligensi dengan proses belajar matematika.

Sifat hirarkis pada matematika mengharuskan bahwa jika konsep A menjadi dasar untuk mempelajari konsep B, maka belajar tentang konsep A adalah sebuah syarat mutlak. Dengan kata lain belajar matematika harus secara bertahap. Menurut Hudojo (1990), untuk mempelajari suatu materi baru matematika, pengalaman belajar yang lalu dari seseorang itu akan mempengaruhi terjadinya proses belajar materi matematika tersebut Seseorang akan lebih mudah mempelajari sesuatu bila belajar itu didasari kepada apa yang telah diketahui orang itu. Hudojo (2004) lebih lanjut mengatakan karena kehirarkian matematika maka belajar matematika yang terputus-putus akan mengganggu terjadinya proses belajar. Dengan kata lain belajar matematika mesti dipelajari secara kontinyu sesuai urutan yang dipersyaratkan.

Belajar matematika juga tidak luput dari sorotan psikologi kognitif. Para ahli psikologi kognitif ini tertarik tentang struktur atau ketentuan urutan dalam matematika. Sebuah kasus menarik yang terkait dengan struktur yakni urutan konsep operasi aljabar bilangan real. Menurut matematika untuk mengajarkan konsep operasi dimulai dari operasi penjumlahan, pengurangan, perkalian kemudian pembagian ("+,,",",,x",,:"). Sedangkan psikolog kognitif berpendapat lain. Menurut mereka urutan yang lebih logis adalah dimulai dari operasi jumlah, kali, kurang kemudian konsep pembagian ("'+","x","-",":"). 
Pakar matematika berpendapat bahwa sesudah operasi jumlah maka diikuti oleh operasi kurang dengan alasan bahwa operasi kurang adalah invers dari operasi jumlah. Sedangkan para psikolog kognitif menganggap bahwa akan terjadi kesulitan mengajarkan operasi kali bila tidak dilakukan sesudah operasi penjumlahan dan seterusnya. Kedua pandangan ini mengemukakan gagasan yang rasional. Dan kebijakan memilih urutan mana yang sebaiknya didahulukan, merupakan keputusan penentu dalam kegiatan pembelajaran seorang guru.

Matematika menganut sistem yang konsisten. Meskipun demikian matematika tidaklah kaku dalam manipulasi sistem. Manipulasi sistem tidak akan berpengaruh sepanjang bergerak dalam sistem yang dianut dan dalam lingkup semesta pembicaraan. Konsep dalam matematika merupakan pegangan sehingga dalam melakukan manipulasi bentuk atau simbol selalu berada dalam koridor sistem yang dianut. Selanjutnya Hudojo (1990) mengatakan, karena matematika merupakan ide-ide abstrak yang diberi simbol-simbol, maka konsep-konsep matematika harus dipahami lebih dahulu sebelum memanipulasi simbol-simbol itu.

\section{Jenis-jenis Belajar Matematika}

Mempelajari matematika memerlukan situasi tersendiri. Selain keterlibatan mental juga harus didukung oleh cara atau proses mempelajarinya. Pada makalah ini akan dijelaskan beberapa jenis belajar matematika, seperti belajar konsep, belajar pengetahuan deklaratif, belajar pengetahuan prosedural dan belajar pengetahuan kondisional.

a. Belajar Konsep (Concept Learning)

Konsep adalah idea abstrak yang dapat digunakan untuk menggolongkan atau mengklasifikasikan sekumpulan obyek, Soedjadi (2000). Apakah obyek tertentu merupakan contoh konsep ataukah bukan. Misalnya, siswa yang telah belajar konsep segitiga maka dengan sendirinya ia mampu mengenali contoh segitiga dan yang bukan contoh segitiga.

Nasution (2006) menjelaskan bahwa bila seorang dapat menghadapi benda atau peristiwa sebagai suatu kelompok, golongan, kelas, atau kategori, maka ia telah belajar konsep. Dienes dalam Ratumanan (2004) membedakan konsep matematika atas; konsep murnii (pure mathematical concepts), yaitu ide matematika tentang klasifikasi bilangan dan relasi antar bilangan, konsep notasi (notational concepts), yaitu tentang sifat bilangan sebagai akibat langsung dari cara penyajiannya dan konsep terapan 
55 | al-Khwarizmi, Volume III, Edisi 1, Maret 2015, Hal. 51 - 62.

(applied concepts), yaitu aplikasi konsep murni dan konsep notasi dalam pemecahan masalah matematika.

Belajar konsep dalam matematika dilengkapi dengan penyertaan definisi dan atribut yang menyertai sebuah konsep. Sebagai contoh, belajar konsep bilangan rasional. Untuk mempelajari konsep bilangan rasional maka secara sederhana dapat diajukan pertanyaan sebagai berikut:

1) Apa definisi bilangan rasional?

2) Konsep apa yang menjadi prasyaratnya?

3) Apa simbol untuk bilangan rasional?

4) Tuliskan contoh dan bukan contoh bilangan rasional!

5) Tunjukkan apakah contoh itu sesuai definisi!

Jawaban lengkapnya sebagai berikut:

1) Bilangan rasional ialah bilangan yang dapat dilambangkan dengan $\frac{a}{b}, b \neq 0, a, b \in B$ dimana a dan b tidak mempunyai faktor persekutuan selain 1

2) Bilangan Bulat

3) $Q$

4) Contoh: $5 ; \frac{2}{3} ; 2,5 ; 4 \frac{1}{2}$

5) Bukan Contoh: $\sqrt{2} ; \sqrt{3}$

6) $\frac{5}{1} ; \frac{2}{3} ; \frac{5}{2} ; \frac{9}{2}$ (bentuk sesuai definisi)

7) Tidak bisa dituliskan sesuai definisi bilangan rasional tetapi dapat dibuktikan (tidak dituliskan di sini).

b. Belajar Pengetahuan Deklaratif, Prosedural dan Kondisional

Pengetahuan deklaratif, pengetahuan prosedural dan pengetahuan kondisional dalam matematika merupakan tiga rangkai pengetahuan yang berkembang secara berkaitan. Gagne (2000) dalam Mohammad Nur mengatakan pengetahuan dibagi dalam tiga kategori yakni; deklaratif, prosedural, dan kondisional. Pengetahuan deklaratif adalah pengetahuan yang dimiliki pembelajar tentang sesuatu, Mohammad Nur (2000). Sebagai contoh dalam matematika adalah pengetahuan tentang konsep, fakta, definisi, rumus.

Pengetahuan prosedural adalah pengetahuan tentang bagaimana melakukan sesuatu, Mohammad Nur (2000). Sebagai contoh dalam matematika yaitu bagaimana menggunakan rumus, definisi untuk menyelesaikan soal. 
Pengetahuan kondisional adalah pengetahuan tentang kapan, mengapa menggunakan pengetahuan deklaratif atau pengetahuan prosedural, Mohammad Nur (2000). Contoh dalam matematika yaitu dalam penggunaan algoritma tertentu. Membedakan lebih tegas tentang ketiga kategori pengetahuan ini dapat dilihat pada tabel berikut:

\begin{tabular}{|l|l|l|}
\hline & $\begin{array}{l}\text { - } \mathrm{x}_{1} \mathrm{x}+\mathrm{y}_{1} \mathrm{y}=\mathrm{r}^{2} \quad \text { (PGS } \\
\text { Lingkaran) }\end{array}$ & \\
$\begin{array}{l}\text { Pengetahuan } \\
\text { Deklaratif }\end{array}$ & $\begin{array}{l}\text { - } y=m x \pm r \sqrt{m^{2}+1} \\
\text { Dua garis saling tegak } \\
\text { lurus maka hasil kali } \\
\text { gradiennya }=-1\end{array}$ & $\begin{array}{l}\text { Pengetahuan } \\
\text { tentang sesuatu }\end{array}$ \\
\hline $\begin{array}{l}\text { Pengetahuan } \\
\text { Prosedural }\end{array}$ & $\begin{array}{l}\text { Dari rumus } \mathrm{x}_{1} \mathrm{x}+\mathrm{y}_{1} \mathrm{y}=\mathrm{r}^{2}, \\
\text { tentukanlah persamaannya } \\
\text { jika diketahui } \mathrm{x}_{1}=4 \text { dan } \mathrm{y}_{1}=\end{array}$ & $\begin{array}{l}\text { Pengetahuan } \\
\text { menggunakan }\end{array}$ \\
\hline $\begin{array}{l}\text { Pengetahuan } \\
\text { Kondisional }\end{array}$ & $\begin{array}{l}\text { Tentukan persamaan garis } \\
\text { singgung lingkaran berpusat } \\
\text { di titik }(0,0) \text { dan panjang jari- } \\
\text { jari=25 yang tegak lurus garis } \\
3 \mathrm{x}-4 \mathrm{y}=25 \text { ! }\end{array}$ & $\begin{array}{l}\text { Pengetahuan } \\
\text { kapan } \\
\text { menggunakan }\end{array}$ \\
\hline
\end{tabular}

\section{Belajar Bagaimana Belajar (Metakognisi)}

Dalam kenyataan ada siswa yang begitu menonjol dalam prestasi belajarnya. Di sisi lain ada juga yang mengalami perkembangan belajar yang begitu lambat. Dua situasi ini telah diteliti oleh ahli pembelajaran maupun psikolog. Mengapa terjadi dua kasus yang demikian berbeda? Menjawab dua kasus berbeda di atas tidak cukup hanya mengatakan bahwa siswa itu berprestasi karena ia pintar. Begitu pun siswa yang tidak berprestasi bukan semata - mata disebabkan karena kebodohannya.

Faktor IQ memang sangat berpengaruh dalam keberhasilan belajar. Tetapi menurut hasil penelitian ahli pembelajaran ternyata ada faktor yang lebih mendominasi sehingga seseorang bisa berhasil dalam belajar. Winkel (1996) mengemukakan tentang hasil penelitian psikologis yang telah menemukan sejumlah ciri dari belajar yang baik, sehingga semua siswa dapat meningkatkan mutu belajarnya. Faktor tersebut adalah faktor kemampuan seseorang belajar menemukan cara belajar yang baik dan cocok untuk dirinya. 
57 | al-Khwarizmi, Volume III, Edisi 1, Maret 2015, Hal. 51 - 62.

Metakognisi adalah sebuah istilah yang banyak didefinisikan para pakar sebagai belajar bagaimana belajar. O'Neil \& Brown dalam Nurdin (2007) mengemukakan metakognisi sebagai proses seseorang berpikir tentang berpikir mereka sendiri dalam membangun strategi menjawab masalah. Sedangkan Tim (2001) mengatakan metakognisi adalah suatu bentuk kemampuan untuk melihat pada diri sendiri sehingga apa yang dia lakukan dapat terkontrol secara optimal.

Masih dalam Nurdin (2007), Huit memperjelas kemampuan metakognisi seseorang dengan mengembangkan pertanyaan terhadap diri sendiri, yaitu:

a) Apa yang saya tahu dari suatu masalah?

b) Apa yang saya butuhkan untuk mengetahuinya?

c) Dari manakah saya mendapatkan informasi untuk mengetahuinya?

d) Berapa lama waktu digunakan untuk mempelajarinya?

e) Apa strategi yang saya pakai untuk mengetahuinya?

f) Cukupkah hanya mendengar, membaca atau dengan melihat untuk dapat memahaminya?

g) Akankah saya tahu dengan mempelajarinya secara cepat?

h) Bagaimana saya dapat membuat sedikit kesalahan jika saya berbuat sesuatu?

Kedelapan pertanyaan ini kiranya dapat menggugah seseorang untuk mengatasi masalah belajar yang dihadapinya. Setiap manusia pembelajar pasti mempunyai potensi. Potensi itu termasuk kemampuan metakognisi. Persoalannya adalah kemampuan metakognisi seseorang terkadang membutuhkan stimulus. Dengan cara memberikan stimulus inilah seseorang dapat dibantu menemukan potensi dirinya. Termasuk kemampuan metakognisi yang dimilikinya.

Seorang guru yang bijak, tidak lantas berputus asa dan membiarkan keadaan siswanya dalam keterpurukan prestasi. Menurut Tim (2001) ada beberapa hal yang dapat digunakan seorang guru untuk menolong siswanya mengembangkan kesadaran metakognisinya, seperti: dengan mengajukan pertanyaan yang berfokus pada "apa" dan "mengapa", mengembangkan aspek pemecahan masalah untuk peningkatan prestasi, dan membiasakan siswa memecahkan masalah secara mandiri.

Sebagai contoh kemampuan metakognisi dapat dideteksi dari pola belajar siswa untuk lebih cepat memahami suatu materi. Dari segi variasi mungkin siswa dapat belajar lebih baik jika mendengarkan musik. Ada juga membaca dengan bersuara 
sehingga melibatkan lebih banyak indera. Dari segi teknik, mungkin seorang siswa membuat peta konsep materi, sehingga memudahkan menjangkau materi secara keseluruhan. Secara khusus dalam belajar matematika seorang anak akan lebih mengerti menentukan himpunan penyelesaian suatu pertidaksamaan kuadrat jika disertai gambar.

Usaha mencari dan menemukan sebagai bentuk eksperimen dari seorang pembelajar tentu akan lebih mempercepat mendapatkan apa yang terbaik untuk dirinya. Dengan demikian akan mengurangi anggapan bahwa keberhasilan belajar hanya didominasi oleh orang yang berinteligensi tinggi saja. Sebab belajar yang baik adalah belajar yang sesuai dengan keadaan seseorang. Belajar harus dinikmati, belajar harus menyenangkan untuk mendapatkan hasil lebih efektif.

\section{Implementasi Teori Belajar dalam Pembelajaran Matematika}

Hal yang lebih kongkrit dari apa yang dibahas di atas adalah penjelasan tentang implementasinya dalam matematika. Belajar konsep, belajar pengetahuan deklaratif, belajar pengetahuan prosedural, belajar pengetahuan kondisional dan belajar bagaimana belajar (metakognisi) secara rinci akan ditampilkan dalam satu topik matematika yaitu perkalian skalar dua vektor.

a) Belajar Konsep

Memahami konsep perkalian skalar dua vektor tentu beranjak dari apa definisinya, yaitu:

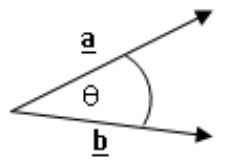

$$
\begin{aligned}
& \underline{\mathbf{a}} \cdot \underline{\mathbf{b}}=\underline{\mathbf{a}} \underline{\mathbf{b}} \operatorname{Cos} \boldsymbol{\theta} \ldots \\
& |\underline{a}|: \text { : }: \text { panjung vektor } \underline{\mathbf{a}} \\
& |\underline{b}|: \text { panjang vektor } \underline{\mathbf{b}}
\end{aligned}
$$

Definisi di atas dapat dikembangkan menjadi rumus yang lebih aplikatif sebagai berikut:

$$
\begin{array}{rr}
\underline{\mathbf{a}} \cdot \underline{\mathbf{b}}=\mathrm{a}_{1} \mathrm{~b}_{1}+\mathrm{a}_{2} \mathrm{~b}_{2}+\mathrm{a}_{3} \mathrm{~b}_{3} & \text { (untuk Vektor di } \mathrm{R}^{3} \text { ) ..............(ii) } \\
\underline{\mathbf{a}}=\mathrm{a}_{1} \mathbf{i}+\mathrm{a}_{2} \mathbf{j}+\mathrm{a}_{3} \underline{\mathbf{k}} & \mathrm{a}_{1}, \mathrm{~b}_{1}, \mathrm{a}_{2}, \mathrm{~b}_{2,} \mathrm{a}_{3}, \mathrm{~b}_{3} \text {, bilangan Real } \\
\underline{\mathbf{b}}=\mathrm{b}_{1} \underline{\mathbf{i}}+\mathrm{b}_{2} \mathbf{j}+\mathrm{b}_{3} \underline{\mathbf{k}} &
\end{array}
$$

Mendapatkan Rumus (ii) memerlukan pengetahuan konsep tentang:
1) vektor $\underline{\mathbf{i}}, \mathbf{j}$, dan $\underline{\mathbf{k}}$
2) $\underline{\mathbf{i}} \cdot \mathbf{j}=\underline{\mathbf{j}} \cdot \underline{\mathbf{i}}=\underline{\mathbf{i}} \cdot \underline{\mathbf{k}}=\underline{\mathbf{k}} \cdot \underline{\mathbf{i}}=\mathbf{j} \cdot \underline{\mathbf{k}}=\underline{\mathbf{k}} \cdot \mathbf{\mathbf { j }}=\mathbf{0}$
3) $\underline{\mathbf{i}} \cdot \underline{\mathbf{i}}=\underline{\mathbf{j}} \cdot \mathbf{j}=\underline{\mathbf{k}} \cdot \underline{\mathbf{k}}=\mathbf{1}$
$\left(\boldsymbol{\theta}=\mathbf{9 0}^{\circ}\right)$
4) perkalian antara $\underline{\mathbf{a}}$ dan $\underline{\mathbf{b}}$ 
59 | al-Khwarizmi, Volume III, Edisi 1, Maret 2015, Hal. 51 - 62.

Bila konsep telah dipahami sepenuhnya maka selanjutnya dapat menjadi kontrol dalam berbagai aplikasi, sehingga kekeliruan (miskonsepsi) dapat dihindari. Meskipun demikian konsep tidaklah berarti mengupas sampai kepada hal-hal yang sangat detail.

b) Belajar Pengetahuan Deklaratif

Semua elemen yang membangun konsep perkalian skalar dua vektor, tersimpan dalam memori dan menjadi preposisi yang berdiri sendiri atau berkelompok (pengetahuan deklaratif). Elemen yang dimaksud adalah definisinya, rumusnya, dan semua yang terkait.

Di antara semua elemen yang tersimpan boleh jadi ada yang benar-benar dipahami dan mungkin juga karena dihafal saja. Preposisi ini menempati suatu ruang dalam memori penyimpanan pengetahuan. Semua elemen tersebut pada saatnya nanti dipanggil untuk menjawab masalah yang membutuhkannya.

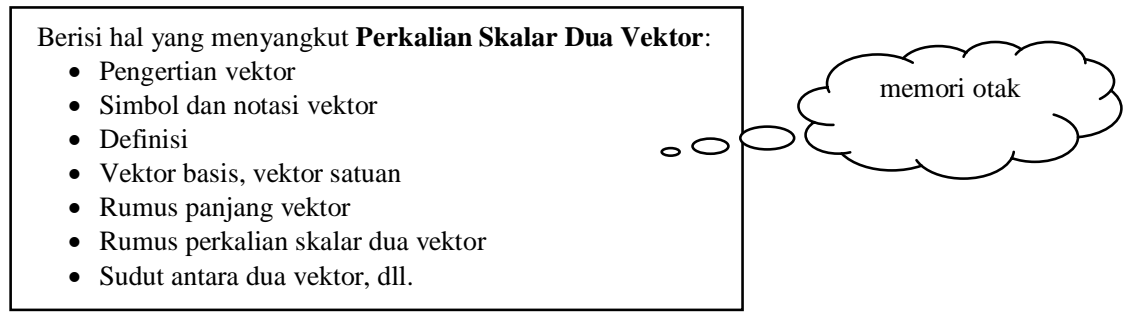

c) Belajar Pengetahuan Prosedural

Berdasarkan penjelasan sebelumnya pengetahuan prosedural memiliki kedudukan yang sangat penting. Pengetahuan konsep, pengetahuan deklaratif dan pengetahuan prosedural bersinergi sehingga aplikasinya menjadi jelas dan terarah.

Dalam materi perkalian skalar dua vektor pengetahuan prosedural menitikberatkan pada:

1) bagaimana cara menggunakan rumus

2) bagaimana memanfaatkan semua elemen yang membangun rumus tersebut sehingga dapat menjawab masalah yang ditanyakan

Pengetahuan prosedural tidak sampai mengupas kepada hal manganalisis suatu masalah. Sehingga diperlukan pengetahuan kondisional.

d) Belajar Pengetahuan Kondisional

Pengetahuan kondisional dalam materi perkalian skalar dua vektor memiliki fungsi lebih dari pengetahuan prosedural. Jika 
pengetahuan prosedural menekankan pada bagaimana cara menggunakan rumusnya, maka pengetahuan kondisional justru berfungsi memberikan arahan kepada kapan rumus itu digunakan.

Belajar pengetahuan kondisional berarti menerapkan logika implikasi (jika.....,maka....). Suatu soal yang dimunculkan akan diolah dengan cara, "jika soalnya begini, maka caranya seperti ini", atau "jika soalnya seperti ini, maka rumus yang digunakan adalah ini".

Perhatikanlah contoh soal berikut ini:

Contoh (1).

1) Diketahui vektor $\underline{\mathbf{a}}=2 \underline{\mathbf{i}}+3 \mathbf{j}+2 \underline{\mathbf{k}}$ dan $\underline{\mathbf{b}}=4 \underline{\mathbf{i}}+5 \mathbf{j}+3 \underline{\mathbf{k}}$. Hasil dari $\underline{\mathbf{a}} \cdot \underline{\mathbf{b}}=\ldots$. Menjawab pertanyaan ini membutuhkan pemahaman konsep, pengetahuan deklaratif dan pengetahuan prosedural.

2) Mengenali bahwa soal ini merupakan perkalian skalar dua vektor adalah pemahaman konsep.

3) Mengingat rumus $\underline{\mathbf{a}} \cdot \underline{\mathbf{b}}=\mathrm{a}_{1} \mathrm{~b}_{1}+\mathrm{a}_{2} \mathrm{~b}_{2}+\mathrm{a}_{3} \mathrm{~b}_{3}$ adalah pengetahuan deklaratif.

4) Menggunakan $\underline{\mathbf{a}} \cdot \underline{\mathbf{b}}=2.4+3.5+2.3=8+15+6=29$ adalah pengetahuan prosedural.

Contoh (2).

1) Tentukanlah nilai $\mathrm{x}$ jika diketahui vektor $\underline{\mathbf{a}}=(3,4, \mathrm{x})$ dan $\underline{\mathbf{b}}=(2,2,7)$ saling tegak lurus. Menjawab soal ini, selain membutuhkan pemahaman konsep, pengetahuan deklaratif, pengetahuan prosedural juga memerlukan pengetahuan kondisional.

2) Mengenali bahwa soal ini merupakan perkalian skalar dua vektor adalah pemahaman konsep.

3) Mengingat rumus $\underline{\mathbf{a}} \cdot \underline{\mathbf{b}}=\mathrm{a}_{1} \mathrm{~b}_{1}+\mathrm{a}_{2} \mathrm{~b}_{2}+\mathrm{a}_{3} \mathrm{~b}_{3}$ adalah pengetahuan deklaratif.

4) Menggunakan $\underline{\mathbf{a}} \cdot \underline{\mathbf{b}}=3.2+4.2+\mathrm{x} .7$ adalah pengetahuan prosedural.

5) Menetapkan $\underline{\mathbf{a}} \cdot \underline{\mathbf{b}}=0$, sehingga

$3.2+4.2+x \cdot 7=0$

$6+8+7 \mathrm{x}=0$

$14+7 \mathrm{x}=0$

$7 \mathrm{x}=-14$

$\mathrm{x}=-2$ adalah pengetahuan kondisional.

e) Metakognisi

Dimana kedudukan metakognisi dalam pemabahasan perkalian skalar dua vektor? Menjawab pertanyaan ini sangat 
61 | al-Khwarizmi, Volume III, Edisi 1, Maret 2015, Hal. 51 - 62.

bergantung kepada si pembelajar. Bagaimana mereka belajar sehingga dapat dengan mudah memahaminya. Tentunya tetap melibatkan jasa guru sebagai fasilitator.

Beberapa cara dapat ditempuh untuk mempelajarinya seperti; menggunakan peta konsep, memperbanyak latihan soal-soal variatif, mendiskusikan baik dengan guru atau teman, atau membuat soal sendiri dan bertukar dengan teman untuk menjawabnya.

\section{Penutup}

Belajar dengan segala seginya tentu berkembang secara dinamis. Perkembangan ini tidak akan pernah berhenti seiring dengan kemajuan budaya manusia. Tetapi yang penting adalah belajar sesuatu termasuk belajar matematika membutuhkan keterlibatan mental, pengetahuan tentang karakteristik suatu ilmu atau pengetahuan, teknik apa yang sesuai dengan keadaan ilmu itu dan keadaan diri seseorang yang belajar.

Pembahasan di atas telah memberi masukan yang berharga tentang bagaimana belajar matematika. Belajar konsep, belajar pengetahuan deklaratif, belajar pengetahuan prosedural, belajar pengetahuan kondisional, dan metakognisi menjadi empat mata rantai yang saling bersinergi untuk memahami masalah dalam matematika.

Tahu apa yang kita tahu, sadar akan apa yang kita tidak tahu akan sangat membantu seseorang bertindak mengatasi masalahnya. Kemampuan untuk itu dapat ditemukan sendiri dan juga dapat dibantu oleh orang lain. Interaksi, kerjasama disertai sikap terbuka atau berterus terang dengan segala kelebihan atau kekurangan akan lebih memperjelas arah tujuan yang hendak diraih. 


\section{DAFTAR PUSTAKA}

Jenis-Jenis Belajar ...| 62

Hudojo Herman. 1990. Strategi Mengajar Belajar Matematika. Malang: IKIP Malang.

Nasution, S. 2006. Berbagai Pendekatan dalam Proses Belajar Mengajar. Jakarta: Bumi Aksara

Nur, Mohammad. 2000. Strategi - Strategi Belajar. Surabaya: UNESA University Press.

Nurdin. 2007. Model Pembelajaran Matemátika yang Menumbuhkan Kemampuan Metakognitif untuk Menguasai Bahan Ajar. Disertasi. Surabaya: Unesa

Ratumanan, T.G. 2004. Belajar dan Pembelajaran. Edisi ke-2. Surabaya: Unesa University Press.

Soedjadi, R. 2000. Kiat Pendidikan Matemátika di Indonesia, Konstatasi Keadaan Masa Kini Menuju Harapan Masa Depan. Jakarta: Ditjen Dikti Depdiknas.

Tim MKPBM. 2001. Strategi Pembelajaran Matemátika Kontemporer. Bandung: JICA - Universitas Pendidikan Indonesia.

Winkel, W.S. 1996. Psikologi Pengajaran. Edisi Revisi. Jakarta: PT. Gramedia Widiasarana Indonesia 